\title{
An Investigation of the Relationships Between Attachment Levels to School and the Variables of the Perception of School Life Quality and Peer Pressure Among High School Students
}

\author{
Cetin Toraman ${ }^{1}$, Burak Aycicek ${ }^{2}$ \\ ${ }^{1}$ Assistant Professor, Canakkale 18 Mart University, Canakkale, Turkey \\ ${ }^{2} \mathrm{Ph} . \mathrm{D}$., Ministry of National Education, Turkey \\ Correspondence: Burak Aycicek, Ph.D., Ministry of National Education, Turkey.
}

Received: October 30, 2018

doi:10.11114/jets.v7i1.3720
Accepted: December 2, 2018 Online Published: December 12, 2018

URL: https://doi.org/10.11114/jets.v7i1.3720

\begin{abstract}
The aim of this study is to investigate the relationships between attachment levels to school and the variables of the perception of school life quality and peer pressure among high school students and whether school life quality and peer pressure predict students' attachment levels to school significantly. The relational screening model was used in the research. The sample group for the research comprised a total sum of 1533 high school students from 12 different high schools in six counties in Hatay province in Turkey. Sample of the study was selected using purposive and easily accessible sampling. "School Attachment Scale Among Children and Adolescents (High School Form) (SASACA)", "The Quality of Life in High Schools Scale (QLHSS)" and "Peer Pressure Scale (PPS)" were used as tools of data collection. A Pearson Correlation analysis was performed to determine whether there was a significant relationship between the scores of the scales used in the study. Considering the findings of the study it was found out that there was a significant and positive relationship between the levels of students' attachment to school and school life quality. In addition, a high level, negative and significant relationship was found between the level of students' attachment to school and peer pressure. Peer pressure and school life quality are significant explanations of the level of attachment to school.
\end{abstract}

Keywords: attachment to school, high school students, school life quality, peer pressure

\section{Introduction}

Schools are the institutions which prepare students to life. Although it should not be underestimated that learning and sharing of knowledge are not only limited to schools (Orakc1, Durnalı, and Özkan, 2018), they are considered as living spaces as well as being educational environments. Children spend a lot of time at schools and interact with other students, teachers, management and school staff (Eres and Bilasa, 2016). In school environment, social and psychological developments of the students are important besides intellectual competencies. Therefore, schools should also contribute to the social and psychological development of the students (Marks, 1998).

School is so important for the development of adolescents that different theories emerge. One of these theories is attachment theory. According to this theory, attachment starts during infancy and its influences continues for as long as individual lives and they can be generalized with relationships established with others (Ainsworth, 1989). In the social learning theory, positive values and standards can be formed via attachment and belonging to social groups (Hawkins, Catalano, Kosterman, Abbott, \& Hill, 1999). School life plays a significant role in getting necessary skills and equipment among adolescents (Chapman, Buckley, Sheehan, \& Shochet, 2013). According to Catalano, Haggerty, Oesterle, Fleming \& Hawkins (2004), schools function as the most important socializing factor providing experience of attachment relationships. Ueno (2009) states that school attachment helps adolescents get a sense of belonging, emotional attachment and satisfaction from school life.

School and teacher are important factors to determine the level of adolescents' attachment to school. Deci and Ryan (2000) states that school helps adoloscents build close relationships and meet their attachment needs; in addition to this, school funtions as one of the most appropriate social environment for adolescents, because they spend most of their time in school (Baker, Dilly, Auperle, \& Patil, 2003). Teacher, as the other attachment figure, are both basic interaction 
source in schools and plays a significant role in students' lives (Sierra, 2012). Teachers are responsible for both in the students' academic development and in their psychosocial development (Myrick, 2003). Also, students who have positive and supportive relationships with their teachers can adapt to their peers and adults in school more easily and build strong relationships and experience less problems (Howes \& Hamilton, 1992).

According to Resnick et al. (1997), factors strengthening school attachment can be listed under four groups. These are: Adult support: It refers to emotional support and care of school personnels to students and spend time with them. Belonging to a positive peer group: Attachment to peers may have a positive effect on students' attitude towards school. Attachment to education: It refers to the beliefs of students who regard school as an important institution for their future and who join school activities. School environment refers to student's perception of physical and psychosocial conditions of school. It is clear that school attachment includes teachers, other adults and peers, their educational lives and experiences, their relationships and experiences at school.

One of the including factors in school attachment is peers. Peers are seen more important than families and peers become the main source of activities (You, 2011). Therefore, it can be said that friends have a great influence on students' attitudes towards school, especially on adolescents. A person is a social being and is in constant interaction with others in the society. This interaction continues from childhood to adulthood. As the children grow older, they begin to spend more time with their friends. They feel the need to communicate and interact with others to support their self-respect and well-being, to socialize and to cope with the problems they face (Acar and K1linç, 2017). Peer groups are defined as small groups in which people at the similar ages and with similar likes and dislikes take part. In peer groups, there is an interaction, cooperative, collaboration, division of labor and expectancy from group members (Esen, 2003). Within this context, peer groups are said to have a direct pressure on individuals. In fact, although Erikson has associated the psychological development of the child with his cognitive development in Psycho-Social Development Theory, he also points out that peers are modeled in this development (Atkinson, Atkinson \& Hilgard, 1995, transfered by Özen and Durkan, 2016).

Peer pressure is an important factor and is defined as an influence exerted by a peer group in encouraging individuals to change their attitudes and values in the direction of group norms (Korir and Kipkemboi, 2014). Peer pressure can provide positive changes in an adolescent's life. Therefore, it is not always seen as a negative phenomenon and it is stated that it also has positive effects. It is emphasized that peer pressure should not be seen as a source of all problems On the other hand, peer pressure can have deadly and negative effects (Lashbrook, 2000). The studies show that peer pressure is directly related to many negative activities such as drug and alcohol use, presenting risky behaviors, low self-confidence, attitudes towards school, social anxiety and depression (Acar and Kılınç, 2017). Moreover, peer pressure affects the students' academic performance, socialization at school (Korir and Kipkemboi, 2014), academic achievements and high level of engagement to school (You, 2011). As seen, peer pressure is a strong determiner in school environment. Within this context, it is vital for educators to understand the complex structure of peer pressure. Therefore, peer pressure should be investigated in order to improve the positive effects of this concept and to prevent the negative effects on students for their psychological developments.

Psychological development of students at school is related with many affective behaviors. One of the important affective behaviors that should be taken into account in school environment is school life quality (Eres and Bilasa, 2016). The root of the concept of school life quality is based on the concept of 'quality of life', which has a more general meaning. From an individual point of view, the quality of life is considered as a general and continuous well-being state and the assessment of this concept is usually focused on positive experiences such as happiness, pleasure and satisfaction and the negative experiences and emotions (Durmaz, 2008). Quality of life expresses life satisfaction levels, positive outlook level to life and the extension of meeting the expectations (Kosterlioğlu and Kosterlioğlu, 2015). Within this context, school life quality includes the satisfaction level about learning experiences offered to students, meeting the students' interests, goals, needs and expectations, methods and techniques used in teaching process, the quality of communication, presence of ethical behavior between the individuals at school, quality of learning experiences and the extent of meeting social, emotional and psychological needs (İlğan, Oğuz and Yapar, 2013; Özen, 2017). Therefore, it can be said that school life quality is a measure of students' attitudes and feelings towards school.

There are many factors affecting and increasing school life quality. It is stated that positive communication between teacher and student relations, active student participation in the teaching process, supportive relations between teachers as students are vital in promoting school life quality (Eres and Bilasa, 2016). The studies show that students with low level of school life quality get low points. As a result, school life quality is said to be directly associated with academic achievement. Moreover, academic motivation is affected by the perceived school life quality (Sun Keung, 1999). Within this framework, school life quality should be examined and the school environment should be designed in a way to increase this concept. By doing so, it is also aimed to increase student motivation, academic performance and positive attitudes towards school, which are desired factors in education. 
With reference to this fact, the aim of this research is to examine whether school life quality and peer pressure predict adolescents' school attachment significantly. Within this context, the following research questions will be addressed:

- Is there a significant relationship between school life quality perceived by students and peer pressure?

- Is there a significant relationship between school life quality perceived by students and levels of attachment to school?

- Is there a significant relationship between peer pressure perceived by students and levels of attachment to school?

- Does school life quality perceived by students predict the school attachment level significantly when the perceived peer pressure is taken as a mediator variable?

\section{Method}

The level of explanations of high school students' attachment levels to school by the variables of school life quality and peer pressure in the research and the relationships between these variables are examined. With this aspect, the study is a correlational study (Büyüköztürk, Kılıç Çakmak, Akgün, Karadeniz and Demirel, 2014; Fraenkel, Wallen and Hyun, 2012).

\subsection{Participants}

A total sum of 1533 high school students from 12 different high schools (one technical and vocational high school from each country and one anatolian high school) in six counties in Hatay province. Outlier elimination is conducted as normal distribution could not be obtained at the end of the normality distribution test conducted via data as described in the data analysis. 1328 high school students participated in this study after these processes. In brief, the sample of the study consist of 1328 high school students. 701 of these students are girls and 627 of them are boys. Sample of the study was selected using purposive and easily accessible sampling; criteria was to select volunteer students. Bringing speed and practicality to the study is the point with this determined sampling method (Yıldırım and Şimşek, 2011). Purposive sampling is composed with the principal of working with a part of the sample (Şenol, 2012).

Table 1. Participants distribution details

\begin{tabular}{lll}
\hline & Frequency (f) & Percentage (\%) \\
\hline Girls & 701 & 53 \\
Boys & 627 & 47 \\
Total & 1328 & 100 \\
\hline $9^{\text {th }}$ grade & 341 & 26 \\
$10^{\text {th }}$ grade & 365 & 27 \\
$11^{\text {th }}$ grade & 348 & 26 \\
$12^{\text {th }}$ grade & 274 & 21 \\
Total & 1328 & 100 \\
\hline Anatolian High School & 673 & 51 \\
Technical and Vocational High School & 655 & 49 \\
Total & 1328 & 100 \\
\hline
\end{tabular}

Data of the study was obtained with 05/16/2018 dated and 32889839-604.01.01-E.9634818 numbered permission of Hatay provincial directorate of national education.

\subsection{Data Collection Tools}

"School Attachment Scale Among Children and Adolescents (High School Form) (SASACA)", "The Quality of Life in High Schools Scale (QLHSS)" and "Peer Pressure Scale (PPS)" were used in this study as tools of data collection.

\subsubsection{School Attachment Scale Among Children and Adolescents (High School Form) (SASACA)}

It was adapted to Turkish from Hill (2005) by Savi Çakar and Karataş (2017). First adaptation was made for 3rd-8th grade and brought to Turkish Culture with three factor scales (teacher, friend, attachment Scale) in 15 items. The scale was structured as five point likert scale. The highest point possible is 75 and getting a high point in the scale shows high level of school attachment. Confirmatory Factor Analysis (CFA) was applied to data obtained from high school students to examine the applicability of the same scale to high school students. According to the results of the DFA, it is proved that the scale is applicable to high school students with 14 items (item 6 removed from the scale) and three dimensions. The reliability level of the scale was determined as .91. Sub-dimensions of the scale are attachment to school, attachment to friends, attachment to teachers.

\subsubsection{The Quality of Life in High Schools Scale (QLHSS)}

It is developed for high school students by Sarı (2011). The scale was structured as five point likert scale. It consists of 35 items. Getting a high point in the scale shows high level of school life quality. The scale consists of seven 
sub-dimensions (teachers, positive feelings towards school, status, school administrators, negative feelings towards school, students and social activities). The reliability of these sub-dimensions are between .68 and .86 . Sub-dimensions of the scale are teachers, positive feeling towards school, status, school administrators, negative feeling towards school, students and social activities

\subsubsection{Peer Pressure Scale (PPS)}

It is developed for high school students by Kiran Esen (2003). The scale was structured as five point likert scale. It consists of 34 items and the highest point is 170. Getting a high point in scale shows high level of peer pressure. The scale consists of two sub-dimensions. Direct peer pressure consists of 19 items and has a reliability level of .89. Indirect peer pressure consists of 15 items and has a reliability of .82. Sub-dimensions of the scale are direct peer pressure and indirect peer pressure.

\subsection{Data Analysis}

In accordance with research questions, correlation analyses and path analysis application are required for data analysis. In path analysis, data are required to show a multivariate normal distribution for variance and covariance matrixes to be positively defined (Özdamar, 2013). Variables in structural equation modeling (SEM) and path analysis are expected to show a multivariate normal distribution. In these analyses; assumptions such as "all univariate distributions are normal", "each variable is normally distributed for each value of each other variable", "all bivariant distributions are linear and distribution of residuals is homoscedastic" are valid. However, as examining all mutual frequency distributions is not practical, evaluating all aspects of multivariate normality can be hard, too. There are statistical tests to determine multivariate normality violations such as Mardia's, Cox-Small's tests. These tests are normally limited to the fact that small separations may be statistically significant in a large sample. Data that does not show multivariate normal distribution can be determined by examining univariate distributions (Kline, 2011).

Moreover, the normal distribution of the obtained data allows us to use "Pearson Product-Moment Correlation Coefficient" If data aren't distributed normally, correlation analysis needs to be calculated with "Spearman's Rank Correlation Coefficient". For this reason, "Kolmogorov-Smirnov Normal Distribution Test" and "Doornik-Hansen Multivariate Normal Distribution Test" were applied to data obtained from the sub-dimensions of School Attachment Scale Among Children and Adolescents (High School Form) (SASACA), The Quality of Life in High Schools Scale (QLHSS) and Peer Pressure Scale (PPS) scales.

The results of the Kolmogorov-Smirnov Normal Distribution Test of the data obtained from 1533 students are summarized in Table 2.

Table 2. Normal distribution test results

\begin{tabular}{lll}
\hline Scale & $\mathrm{N}$ & $\mathrm{p}$ \\
\hline School Attachment Scale Among Children and Adolescents (SASACA) & 1533 & 0,151 \\
\hline The Quality of Life in High Schools Scale (QLHSS) & 1533 & 0,061 \\
\hline Peer Pressure Scale (PPS) & 1533 & 0,033
\end{tabular}

As seen in Chart 2, points obtained from sub-dimensions SASACA and QLHSS shows normal distribution ( $>$.05), but points obtained from sub-dimensions PPS doesn't show normal distribution $(\mathrm{p}<.05)$. Outliers elimination is conducted on data of subscales which doesn't show normal distribution (Kalayc1, 2005). After the outliers elimination is conducted, data of 1328 participants were left. Kolmogorov-Smirnov Normal Distribution Test was applied to data of 1328 participants again. Test results are summarized in table 3.

Table 3. Normal distribution test results after the outliers elimination

\begin{tabular}{lll}
\hline Scale & $\mathrm{N}$ & $\mathrm{p}$ \\
\hline SASACA & 1328 & 0,200 \\
\hline QLHSS & 1328 & 0,124 \\
\hline PPS & 1328 & 0,200
\end{tabular}

As seen in Table 3, normal distribution in data left after outliers elimination is provided. Normal distribution examined as univariate is also examined under the assumption of multivariate normal distribution. Obtained data are transferred to STATA 14 package program to examine whether they show multivariate normal distribution or not. Multivariate normal distribution examination can be carried out in STATA program via "Doornik-Hansen Test". Test results are summarized in table 4. 
Table 4. Doornik-Hansen multivariate normal distribution test results

\begin{tabular}{llll}
\hline Variables & $\boldsymbol{X}^{\mathbf{2}}$ & sd & $\mathbf{p}$ \\
\hline SASACA*QLHSS*PPS & 8,50 & 24 & 0,105 \\
\hline
\end{tabular}

When Table 4 is examined, it was found that total of 12 subscales in three different scales show a multivariate normal distribution ( $\mathrm{p}>$.05). In accordance with the results obtained, it has been decided to conduct correlation analyses with "Pearson Product-Moment Correlation Coefficient" and to apply a path analysis model.

\section{Results}

\section{School Life Quality* Peer Pressure * Attachment to School Relationships}

The relationship between school life quality perceived by students, peer pressure and attachment to school is examined. The results obtained are summarized in table 5 .

Table 5. Relationship between perceived school life quality, peer pressure and attachment to school

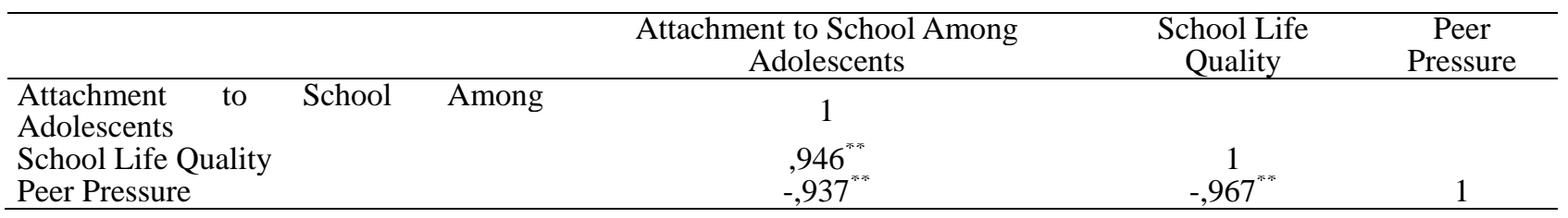
$* \mathrm{p}<.05, * * \mathrm{p}<.01$

As seen in table 5, it is determined that school life quality perceived by students has a high level, significant and positive relationship $(\mathrm{p}<.05)$ with attachment to school. It is found that school life quality has a high level, significant and negative relationship ( $\mathrm{p}<.05)$ with peer pressure. It is seen that attachment to school has a high level, significant and negative relationship $(\mathrm{p}<.05)$ with peer pressure. As peer pressure increases, perceived school life quality and attachment to school decrease. As perceived school life quality increases, attachment to school also increases.

\section{The impact of Perceived School Life Quality on the School Attachment Level in Peer Pressure As a Media}

It is aimed to examine the impact of perceived school life quality on the school attachment level when the perceived peer pressure is taken as a media This examination is conducted with path analysis. The diagram of the path analysis is shown in Figure 1.

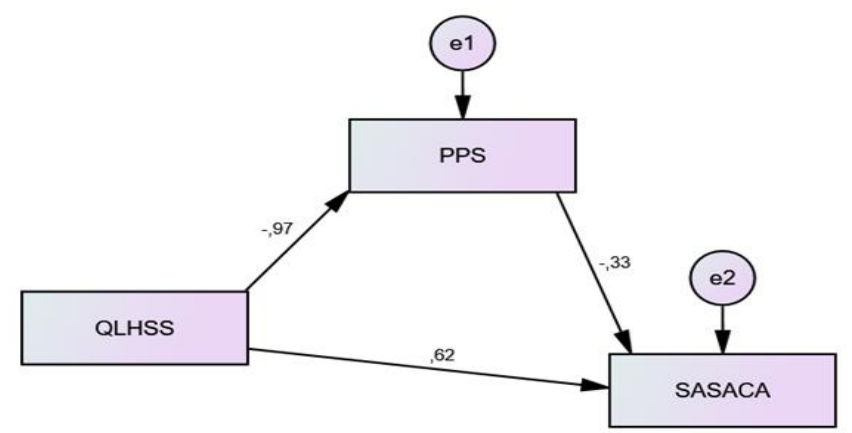

Figure 1. The impact of perceived school life quality on the school attachment level in peer pressure as a media The fit indices of path analysis are summarized in table 6.

Table 6. Fit indexes of path analysis

\begin{tabular}{lc}
\hline \multicolumn{1}{c}{ Fit Index } & Rate \\
\hline Ki-Squared $\left(X^{2}\right)$ & 6713.608 \\
Degree of Freedom (df) & 3 \\
$X^{2} / \mathrm{df}$ & 2237.869 \\
Goodness of Fit Index (GFI) & 0.000 \\
Root Mean Square Error of Approximation (RMSEA) & 1.298 \\
Root Mean Square Residual (RMR) & 0.000 \\
\hline
\end{tabular}

Jöreskog and Sörbom (1993), Sumer, (2000) Özdamar, (2013) Şimşek, (2007) state that these values do not indicate acceptable fitness. According to the results, it can not be said that direct and indirect peer pressure through the 
established path analysis is a significant mediator variable. The results of regressions made by path analysis are summarized in table 7.

Table 7. Relationship of perceived peer pressure and attachment scale

\begin{tabular}{lcccc}
\hline \multicolumn{1}{c}{ Effects } & Estimate & Standard Error & $\begin{array}{c}\text { Critical } \\
\text { Ratio (C.R.) }\end{array}$ & $\mathrm{p}$ \\
\hline School Life Quality $\rightarrow$ Peer Pressure & -1.247 & 0.009 & -138.176 & 0,000 \\
School Life Quality $\rightarrow$ Attachment to School Among Adolescents & 0.318 & 0.017 & 18.505 & 0,000 \\
Peer Pressure $\rightarrow$ Attachment to School Among Adolescents & -0.132 & 0.013 & -9.927 & 0,000 \\
\hline
\end{tabular}

When table 7 and figure 1 are examined, correlation value of the indirect effect of perceived school life quality on peer pressure has decreased from -0.97 to -0.33 . As Baron and Kenny (1986, p. 1176) state, full mediating variable effect shows the ability to zero the relationship between explanatory variable and explained variable. Mediator variable decreased the relationship in this analysis but the last relationship obtained $(\mathrm{r}=-0.33)$ is significant. Indirect effect of mediating variable is significant $(\mathrm{p}<.05)$.

According to the direct effects seen on table 6;

- Perceived school life quality is a negative significant predictor $(\mathrm{p}<.05)$ of peer pressure.

- Perceived school life quality is a positive significant predictor $(\mathrm{p}<.05)$ of school attachment.

- Peer pressure is a negative significant predictor $(\mathrm{p}<.05)$ of attachment to school.

Critical ratios for these estimations are less than the critical threshold of 1.96 for the .05 significance level.

\section{Discussion}

In this study, it was aimed to determine the relationship between the school attachment level and perceived peer pressure and school life quality level of high school students. In the first sub-question of the study, the relationship between the school attachment level and perceived school life quality of the high school students and the peer pressure is examined. The results showed that there is a significant, positive and high level relationship between the school attachment level and perceived school life quality [r=.94]. Therefore, it can be said that when the perceived school life quality level of the students increases, the school attachment level of the students will also increase. School life quality is a vital part of education and it has a great importance for students to achieve the desired goals (Mok and Flynn, 1997). Students with high quality of school life level can reach the determined educational goals at maximum level (Sar1, 2007). School life quality is directly associated with students' well beings. Moreover, it affects academic success, motivation and performance of the students (Eres and Bilasa, 2016). In literature, it is stated that when students feel secure at school, they feel more confident and have more satisfaction. Sarı (2007) states that the time students spend with their teacher is valuable and this duration should include entertaining events. If the attitudes of the students towards school are positive, students' perception of life quality increases. On the other hand, attachment to school has a great role in the success or failure of the students. It has a direct relationship between many factors such as self-esteem, motivation, effort, behaviour and academic achievement (Mouton, Hawkins, McPherson and Copley, 1996). In their study Mouton and Hawkins (1996) found that students with low school attachment level feel alone and isolated at school. Moreover, they feel that they do not get enough support from school staff and peers. Cooper (2008) states that low school attachment level may lead to alienation at school with the negative feeling. As a result, school environment should be organized in a way that school life quality will increase. School attachment level will also increase with high quality of school life.

When the relationship between school attachment level and peer pressure is examined, it is found that there is a significant, negative and high level relationship between the school attachment level and peer pressure level [r=-.93]. In other words, when peer pressure increases, school attachment level of the student will decrease. As seen clearly, peer pressure is a negative factor for students. Peer pressure affects individuals' behaviors especially during the high school years (Brown, 1982). Students, especially adolescents, are easily affected by their friends. Peer pressure has a great influence on various variables related to school such as school attitudes and behaviors (You, 2011).

On the other hand it is found that there a significant, negative and high level relationship between school life quality level and peer pressure level [r=-.96]. In other words, when peer pressure increases, school life quality level of the student will decrease. Sar1 (2007) found that in school environment friendship is a predictor of students' life satisfaction. Therefore, as a result of life satisfaction students' school life quality will also increase depending on the relationship with friends. Bilgiç (2009) reached the conclusion that engagement with friends is a predictor of students' life quality. Johnson and Stevens (2001) states that when students feel safe at school environment, level of school life quality increases. As a result, it can be said that peer pressure and school life quality are the two important factors affecting success and performance. Therefore, school environment should be organized in a way that negative peer pressure is decreased. 
In the last sub-question of the study it is aimed to examine the impact of perceived school life quality on the school attachment level when the perceived peer pressure is taken as a media. For this purpose path analysis was conducted. The results showed that perceived school life quality predicts the peer pressure in a negative direction. Secondly, perceived school life quality predicts the school attachment level in a positive way. Lastly, peer pressure predicts the school attachment in a negative way.

\section{References}

Acar, H., \& Kılınç, M. (2017). Effect of psychoeducation program prepared in terms of coping with peer pressure on high school students' level of peer pressure. Mehmet Akif Ersoy University Journal of Social Science Institute, 9(19), 287-300.

Ainsworth, M. D. S. (1989). Attachments beyond infancy. American Psychologist, 44, 709-716. https://doi.org/10.1037/0003-066X.44.4.709

Baker, J. A., Dilly, L. J., Aupperlee, J. L., \& Patil, S. A. (2003). The developmental context of school satisfaction: Schools as psychologically healthy environments. School Psychology Quarterly, 18, 206-221. https://doi.org/10.1521/scpq.18.2.206.21861

Baron, R. M., \& Kenny, D. A. (1986). The moderator mediator variable distinction in social psychological research: Conceptual, strategic, and statistical considerations. Journal of Personality and Social Psychology, 51(6), 1173-1182. https://doi.org/10.1037/0022-3514.51.6.1173

Bilgiç, S. (2009). Investigation of the relationships between the perception of school life quality and the variables of attachment to friends and empathic classroom atmosphere among elementary school students (Unpublished master's thesis). Cukurova University, Adana, Turkey.

Brown, B. B. (1982). The extent and effects of peer pressure among high school students: A retrospective analysis. Journal of Youth and Adolescence, 11(2), 121-133. https://doi.org/10.1007/BF01834708

Büyüköztürk, Ş., Kılıç, Ç. E., Akgün, Ö. E., Karadeniz, Ş., \& Demirel, F. (2014). Scientific Research Methods. Ankara: Pegem.

Catalano, R., Haggerty, K., Oesterle, S., Fleming, C., \& Hawkins, J. (2004). The importance of bonding to school for healthy development: Findings from the social development research group. Journal of School Health, 74, 252-261. https://doi.org/10.1111/j.1746-1561.2004.tb08281.x

Chapman, R., Buckley, L., Sheehan, M. C., \& Shochet, I. M. (2013). School-based programs for increasing connectedness and reducing risk behavior: a systematic review. Educational Psychology Review, 25(1), 95-114. https://doi.org/10.1007/s10648-013-9216-4

Cooper, P. (2008). Nurturing attachment to school: Contemporary perspectives on social, emotional and behavioural difficulties. Pastoral Care in Education, 26(1), 13-22. https://doi.org/10.1080/02643940701848570

Deci, E. L., \& Ryan, R. M. (2000). The "what" and "why" of goal pursuits: Human needs and the determination of behavior. Psychological Inquiry, 11, 227-268. https://doi.org/10.1207/S15327965PLI1104_01

Durmaz, A. (2008). Quality of school life in high schools (the case of Kurklareli province) (Unpublished master's thesis). Trakya University, Edirne, Turkey.

Eres, F., \& Bilasa, P. (2016). Middle school students' perceptions of the quality of school life in Ankara. Journal of Education and Learning, 6(1), 175-183. https://doi.org/10.5539/jel.v6n1p175

Esen, B. K. (2003). The development of peer pressure scale: Studies on the validity and reliability. Eğitim Bilimleri ve Uygulama, 2(3), 65-76.

Fraenkel, J. R., Wallen, N. E., \& Hyun, H. H. (2012). How to design and evaluate research in education. USA: McGraw-Hill.

Hawkins, J. D., Catalano, R. F., Kosterman, R., Abbott, R., \& Hill, K. G. (1999). Preventing adolescent health-risk behaviors by strengthening protection during childhood. Arch Pediatr Adolesc Med, 153(3), 226-234. https://doi.org/10.1001/archpedi.153.3.226

Howes, C., \& Hamilton, C. E. (1992). Children's relationships with child care teachers: Stability and concordance with parental attachments. Child Development, 63, 867-878. https://doi.org/10.2307/1131239

İlğan, A., Oğuz, E., \& Yapar, B. (2013). Examining relationship between perceived quality of school life and academic motivation's level (Sample of Menderes county). Abant İzet Baysal University Education Faculty Journal, 13 (2), 157-176. 
Johnson, B., \& Stevens, J. J. (2001). Exploratory and confirmatory factor analysis of the School Level Environment Questionnaire (SLEQ). Learning Environments Research, 4 (3), 325-344. https://doi.org/10.1023/A:1014486821714

Jöreskog, K. G., \& Sörbom, D. (1993). Lisrel 8: Structural equation modeling with the simplis command language. Hillsdale: Erlbaum.Kalaycı, Ş. (2005). Multivariate statistical techniques with SPSS applied. Ankara: Asil Publication.

Kıran, E., B. (2003). The development of peer pressure scale: Studies on the validity and reliability. Educational Sciences and Practice, 2 (3), 65-76.

Kline, R. B. (2011). Principles and practice of structural equation modeling. USA: The Guilford.

Korir, D. K., \& Kipkemboi, F. (2014). The impact of school environment and peer influences on students' academic performance in Vihiga County, Kenya. International Journal of Humanities and Social Science, 4(1), 240-251.

Kosterelioğlu, M. A., \& Kosterelioğlu, I. (2015). Effects of high school students' perceptions of school life quality on their academic motivation levels. Educational Research and Reviews, 10(3), 274-281. https://doi.org/10.5897/ERR2014.1927

Lashbrook, J. T. (2000) Fitting in: Exploring the emotional dimension of adolescent peer pressure. Adolesence, 35(140), 747-757.

Marks, G. N. (1998). Attitudes to school life: Their influences and their effects on achievement and leaving school. Australia: Australian Council for Educational Research.

Mok, M. M. C., \& Flynn, M. (1997), Does school size affect quality of school life?. Issues in Educational Research, 7(1), 69-86.

Mouton, S. G., Hawkins, J., McPherson, R. H., \& Copley, J. (1996). School attachment: Perspectives of low-attached high school students. Educational Psychology, 16(3), 297-304. https://doi.org/10.1080/0144341960160306

Myrick, R. D. (2003). Developmental guidance and counseling: A pratical approach. USA: Educational Media.

Orakc1, Ş., Durnal, M., \& Özkan, O. (2018). Economic and Geopolitical Perspectives of the Commowealth of Independent States and Eurasia. In (Ed.), Curriculum Reforms in Turkey (pp. 201-224), Hershey, PA: IGI Global.

Özdamar, K. (2013). Statistical data analysis with software packages. Eskişehir: Nisan.

Özen, F. (2017). Change in the perception of teaching profession ethics by primary school teachers and student primary school teachers over time. OPUS International Journal of Society Research, 7(13), 379-398. https://doi.org/10.26466/opus.331158

Özen, F., \& Durkan, E. (2016). The relationship between perceived organizational ethical climate and teaching professional ethics. Educational Administration: Theory and Practice, 22(4), 593-627. https://doi.org/10.14527/kuey.2016.023

Resnick, M. D., Bearman, P. S., Blum, R. W., Bauman, K. E., Harris, K. M., Jones, J., et al. (1997). Protecting adolescents from harm: Findings from the National Longitudinal Study on Adolescent Health. JAMA, 278(10), 823-832. https://doi.org/10.1001/jama.1997.03550100049038

Sarı, M. (2007). The Effect of hidden curriculum on gaining democratic values: A qualitative study in two elemantary schools having low and high quality of school life (Unpublished doctoral dissertation). Cukurova University, Adana, Turkey.

Sarı, M. (2011). Reliability and validity of the quality of life in high schools scale. Journal of Çukurova University Institute of Social Sciences, 20(3), 253-266.

Savi, Ç. F., \& Karataş, Z. (2017). Adolescents' self-esteem, school anger and life satisfaction as predictors of their school attachment. Education and Science Journal, 42(189), 121-136. https://doi.org/10.15390/EB.2017.6573

Şenol, Ş. (2012). Research and sampling methods. Ankara: Nobel.

Sierra, P. G. (2012). Attachment and preschool teacher: An opportunity to develop a secure base. International Journal of Early Childhood Special Education (INT-JECSE), 4(1), 1-16.

Şimşek, Ö. F. (2007). Introduction to structural equation modelling: Basic principles and LISREL applications. İstanbul: Ekinoks.

Sun-Keung, N. P. (1999). Students' perceptions of quality of schoollife in Hong Kong primary schools. Educational Research Journal, 14(1), 49-71. 
Ueno, K. (2009). Same-race friendships and school attachment: Demonstrating the interaction between personal network and school composition. Sociological Forum, 24(3), 515-537.

https://doi.org/10.1111/j.1573-7861.2009.01118.x

Yıldırım, A., \& Şimşek, H. (2011). Qualitative research methods in the social sciences. Ankara: Seçkin.

You, S. (2011). Peer influence and adolescents' school engagement. Procedia-Social and Behavioral Sciences, 29, 829-835. https://doi.org/10.1016/j.sbspro.2011.11.311

\section{Copyrights}

Copyright for this article is retained by the author(s), with first publication rights granted to the journal.

This is an open-access article distributed under the terms and conditions of the Creative Commons Attribution license which permits unrestricted use, distribution, and reproduction in any medium, provided the original work is properly cited. 